\title{
Inflation - Growth Nexus in Sri Lanka: Is there a Threshold Level of Inflation for Sri Lanka?
}

\author{
B.G. Nilupulee De Silva ${ }^{12}$
}

\begin{abstract}
It is of significant economic importance to investigate the relationship of the inflation-growth nexus in Sri Lanka, to identify whether there is a linear or non-linear relationship between the two macro variables. This can lead to the discovery of the threshold level of inflation for Sri Lanka. Accordingly, this research explores the inflation-growth relationship in Sri Lanka, using annual data from 1965 to 2014. The results reveal an inflation rate of 9 per cent, which maximises the per capita GDP growth rate in Sri Lanka. However, the results do not confirm any significant structural break in per capita GDP growth rate when the inflation rate exceeds 9 per cent. Therefore, based on the findings, there is no statistically significant evidence to suggest the existence of a non-linear relationship between per capita GDP growth and inflation in Sri Lanka. Some conjectures, such as errors in data and not including savings and investment data can be made regarding the non-existence of a significant inflation threshold. Furthermore, the findings highlight that there is no negative effect of inflation towards the GDP per capita growth at any rate of inflation in Sri Lanka. This is an indication that any adverse effects of contemporaneous inflation are neutralized due to the significant positive effects from the inflation lag of two years. Furthermore, the results are not in favour of the view of maintaining inflation at low levels and thus, this study is important for policymakers in Sri Lanka, when implementing inflation targeting in Sri Lanka in the future.
\end{abstract}

Keywords: Per-capita income growth, Inflation threshold, Structural break, Sri Lanka

JEL Classification: C22, E00, 011

\footnotetext{
${ }^{1}$ Senior Assistant Director of International Operations Department of the Central Bank of Sri Lanka.

${ }^{2}$ I wish to thank Professor Kaliappa Kalirajan, Professor Renee Mckibbin and Anne Patching of the Australian National University, Australia for their valuable comments in writing this paper. Any errors and omissions are, however, mine.
} 


\section{Introduction}

Most of the development policy objectives of an emerging economy revolve around achieving rapid and sustainable economic growth. Yet, when rapid growth is achieved, as a result of increasing pressure on inputs utilized by excess demand, prices can increase. Hence, sustaining high growth requires that inflation be kept under control, if a rise in inflation causes negative effects on economic growth. The study of the inflation- growth nexus in developing countries is vital to understand the true nature of the relationship between inflation and growth, as maintaining excessively low inflation can lead to high unemployment and reduced output (Philips curve 3 ). This can create inadvertent consequences to economic growth in developing countries. In view of this, Pollin and Zhu identify a positive nexus between Gross Domestic Product (GDP) growth and high inflation up to 15-18 per cent for 80 middle and low income countries, where they argue that targeting inflation at low levels of around 3-4 per cent may not be optional for emerging economies and doing so could harm economic growth (593).

A number of empirical studies, which are discussed in detail under Section Two, have shown that high inflation can be costly and can affect the macroeconomic stability of the country. A study based on data from Latin American countries reveals that there is a negative relationship between inflation and GDP per capita growth (Gregorio 59). Barro shows that when inflation exceeds 10 per cent, the per capita GDP growth rate reduces by $0.2-0.3$ percentage points (19). A similar inflation threshold is evident in a study by Espinoza et al., where they conclude that for developing countries, a significant structural break in per capita GDP growth is caused by an inflation rate above 10 per cent (100).

A study that was carried out using data from 86 countries including Sri Lanka, found a structural break in per capita GDP growth at 8 per cent of inflation rate for emerging and developed nations and suggests that if such a significant structural break for per capita GDP growth exists for a country, and the failure on the part of policymakers to take into consideration the same will impose a greater bias on the inflation effect towards GDP growth (Sarel 203). Sarel further emphasises that the existence of a structural break provides a numerical policy target for Central Banks to maintain inflation below the structural break (213). He is the first to identify the detrimental effects of high inflation by taking into account the structural break in growth in GDP. He points out that when the inflation rate doubles (for example, an increase in inflation from 20 percent to 40 percent), the growth rate declines by 1.7 percentage points (214).

One of the core objectives of the Central Bank of Sri Lanka is to maintain economic stability by controlling inflation, which may be harmful to the economy. The lack of well-researched

\footnotetext{
${ }^{3}$ Philips Curve is a historical inverse relationship between rates of unemployment and corresponding rates of inflation that result in an economy.
} 
and published papers regarding the threshold level of inflation for Sri Lanka, which quantifies any significant structural break of GDP per capita growth in Sri Lanka, creates a research gap in this field of studies. Motivated by the identified research gap and also by the findings of Sarel (213), this study attempts to explore whether such a structural break for per capita GDP growth exists in the Sri Lankan context. Accordingly, this research explores the inflationgrowth nexus in Sri Lanka, using annual data from 1965 to 2014. Principally, this paper addresses whether there is any inflation threshold that maximises per capita GDP growth for Sri Lanka. If any, is the effect of inflation on growth in per capita GDP significantly different above the threshold level from what it is below the inflation threshold.

This study mainly follows the methodology used by Sarel, (207) and Hayat and Kalirajan (8). The results of this study reject the argument that the inflation rate and per capita GDP growth rate in Sri Lanka has a non-linear relationship. Accordingly, there is no statistically significant evidence to suggest the existence of a non-linear relationship between per capita GDP growth and inflation in Sri Lanka. Nevertheless, the study reveals an inflation rate of 9 per cent, which maximises the per capita GDP growth rate. However, the results do not confirm any statistically significant structural break in per capita GDP growth rate at the 9 per cent of inflation.

The structure of the remainder of the paper is as follows. Section Two reviews the empirical literature on the inflation-growth nexus. Section Three includes data and the methodology used in the study, followed by a summary of the results and an analysis in Section Four. Finally, Section Five discusses the limitations and policy implications, and concludes, suggesting future extensions of this study.

\section{Literature review}

A survey of the available theoretical and empirical literature is carried out with a view to enlighten policy makers on the on-going debate of the inflation- growth nexus and also to discover the threshold level of inflation, if any, for Sri Lanka. Many previous empirical studies have analysed the inflation growth nexus in developing countries as well as developed countries and there is evidence for both a positive and negative relationship between inflation and growth. More interestingly, the non-linearity of the inflation and growth relationship has been identified in many country specific studies as well as cross country analyses which include both developing and developed countries. Previous studies have been categorized according to the nature of the inflation-growth nexus and salient features are briefly explained.

\subsection{Positive relationship}

Latin American countries experienced high double-digit inflation along with moderate growth during the 1950s and 1960s, and Bruno and Easterly researched the behaviour of growth in pre, during and post high inflation periods (3). They found that there is no permanent harm 
to growth from high inflation rates (25). A short run positive relationship between inflation and growth is recognized by the Keynesian and Neo-Keynesian theories (Hayat \& Kalirajan 3), whereas a long - run positive relationship is established by Mallik and Chowdhury (133) using error correction models for four South Asian countries-Bangladesh (1974-97), India (1961-97), Pakistan (1957-97), and Sri Lanka (1966-97), implying that these countries needed inflation for growth. However, these results contrast with the discoveries of Hayat and Kalirajan for Bangladesh for the period 1976-2005 (14).

In the context of developed countries, Feldstein considers a two percent inflation rate as a benchmark of price stability by Feldstein and calculates the perpetual benefit of reducing inflation in the United States from two- percent "true" inflation to zero percent "true" inflation (50). Khan and Senhadji establish a 11 per cent threshold for developing countries and 1 per cent for industrialised countries (12). According to Ghosh and Phillips, the appropriate rate is 2.5 per cent (672), whereas Judson and Orphanides conclude a double-digit inflation threshold (117). Moreover, the aggregate supply equation with imperfect information, sticky wages and sticky prices explains a positive link between prices and output. According to the Phillips curve equation, low inflation is related with lower output or increased unemployment (Cooray 3).

\subsection{Negative correlation}

Several studies have explored the negative relationship between inflation and growth and according to the conventional neo-classical view, there is a negative relationship between inflation and growth (Barro 423). Fisher suggests that there are two major routes through which uncertainty caused by high inflation affects the growth of a country (485). Accordingly, uncertainty brings macroeconomic instability and in turn reduces the efficiency of the price mechanism and secondly, uncertainty reduces the investments in a country due to the high volatility in prices (Fischer 485).

Another study carried out by Gregorio, on 12 Latin American countries for the period 19501985, identifies a negative relationship between inflation and growth (59). Moreover, Barro emphasises the argument that growth is expedited during the periods of low inflation, where he highlights that the growth rate of GDP per capita decreases by $0.2-0.3$ percentage points when the average inflation rate exceeds by 10 percentage points (19) according to his study of 100 countries during the 1960 to 1990 time period. In addition, Hodge argues that the growth rate declines by 0.25 percentage points for a percentage point increase in the inflation rate in South Africa (163).

Moreover, Jha and Dang examine the effect of economic growth and inflation variability using annual data from both developing and developed countries (1). The said study which included 182 developing countries and 31 developed countries covering the period 1961-2009, suggests 
that there is significant evidence that beyond the 10 percent inflation rate, inflation variability has a harmful effect on economic growth for developing countries and there is no such significant evidence in the context of developed countries (10).

\subsection{Non-linear relationship of inflation and growth}

The above summary of literature gives evidence to both the positive and negative relationship between inflation and growth. As mentioned earlier, many studies highlight the negative relationship beyond a particular level of rate of inflation (Barro 19), (Jha \& Dang 10). The study by Fischer, which is regarded as the first research that identified a non-linear relationship between inflation and growth, highlighted that low inflation rates have a positive impact on growth (485). It is further argued that inflation leads to a reduction in investment and productivity growth and hence, beyond a threshold limit, inflation has an adverse effect on economic growth (Sarel 199). Further, Pollin and Zhu reveal a positive relationship between output growth and high inflation up to 15-18 per cent of the inflation threshold level and their estimates for 80 middle and low income countries for the period 1961-2000 (593). These findings suggest that targeting inflation at low levels around 3-4 per cent is not really necessary for emerging economies and doing so might harm economic growth.

The non-linearity of the inflation-growth nexus has been investigated in a research done by Mohanty et al., which takes into consideration the structural changes of the Indian economy (14). They suggest an inflation threshold between 4 - 5.5 per cent for India (14). However, an earlier study by Singh identifies the inflation threshold level for India as 6 per cent (3209). Furthermore, using annual data for the period 1971-1998, Singh and Kalirajan attempt to find the inflation threshold for India (377). Yet, they found that there is no significant structural break or an inflation threshold for India and conclude that any level of rise in inflation will have a negative effect on GDP growth rate for India (377). Similarly, Sepheri and Moshiri adopted the same methodology used by Sarel for four different group of countries that are in various stages of development (191). The results indicated that the inflation-growth nexus is non-linear for all groups except for $\mathrm{OECD}^{4}$ countries where, the inflation threshold is 21 percent for lower-middle income countries, 15 percent for low-income countries and 4 percent for upper-middle income countries (191).

According to the results of Espinoza et al.'s study, which examined 165 countries over the period 1960-2007, it is evident that for developing countries inflation above a threshold of about 10 percent rapidly becomes unfavourable to growth (12), implying the need to take

\footnotetext{
${ }^{4}$ OECD -The Organization for Economic Cooperation and Development comprises a group of countries which account for 63 percent of world GDP, three-quarters of world trade, 95 percent of world official development assistance, over half of the world's energy consumption, and 18 percent of the world's population.
} 
immediate policy actions to maintain inflation at a single digit level. However, in the context of advanced economies, threshold effect has not been proven and hence any level of inflation damages growth (Espinoza et al. 12). Furthermore, by using panel data and the Panel Smooth Transition Regression (PSTR) method on the Southern African Development Community, Seletang et al. reveal an inflation threshold of 18.9 per cent, beyond which, there will be harmful effects on the economic growth (149).

\section{Data and Methodology}

The rate of inflation in Sri Lanka is measured by the change in the Colombo Consumer Price Index (CCPI). The CCPI is computed to indicate average changes in the prices of goods and services purchased by households in urban areas of the Colombo district, the Capital city of Sri Lanka. The consumer basket includes 373 items that represent the usual urban households' consumption expenditure. The CPI weights are derived from the Household Income and Expenditure Survey (HIES) 2006/2007. The Department of Census and Statistics (DCS) released a new National Consumer Price Index (NCPI) on November 23, 2015, which reflects more recent changes in the patterns of consumption and expenditure, as revealed by the HIES.

During the 1950s and 1960s the inflation rate in Sri Lanka was 0.7 percent and 2.2 percent, respectively (Cooray 7). However, with the introduction of the open economy in 1977, the rate of inflation started to accelerate and the Sri Lankan economy experienced a high inflation rate (on average more than 10 per cent per annum) during the 1980s, 1990s until about 2009. However, inflation was managed at a single digit level for the last five years since then (CBSL 1). According to Table 1 and Figure 2, the average GDP per capita growth in Sri Lanka tends to decline when the rate of annual inflation exceeds 10 per cent. Further, Figure 1 shows that during periods with single digit annual inflation, the GDP per capita growth in Sri Lanka also increased.

Figure 1: Inflation- GDP Per Capita growth relationship in Sri Lanka, 1965-2014

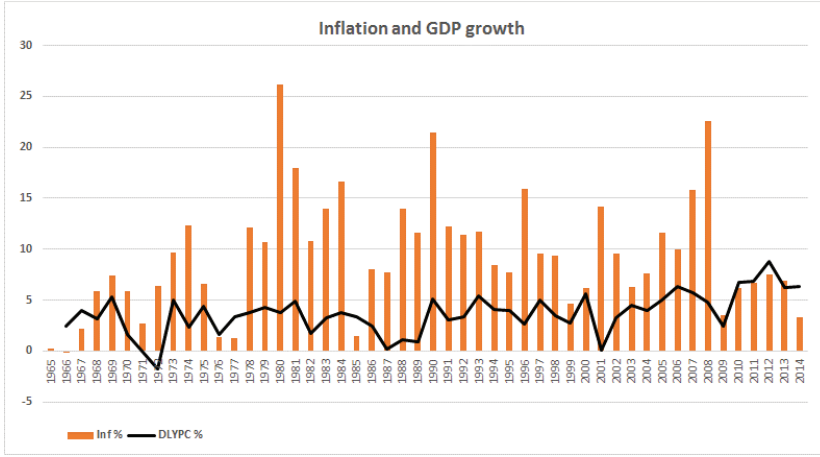

Source: CBSL, DCS 
Table1: Inflation- GDP per capita growth relationship in Sri Lanka, 1965-2014

\begin{tabular}{lc}
\hline \hline Inflation Range (\%) & $\begin{array}{c}\text { Average GDP per } \\
\text { capita Growth }(\%)\end{array}$ \\
\hline $0-2$ & 2.71 \\
$2-4$ & 3.17 \\
$4-6$ & 2.54 \\
$6-8$ & 4.40 \\
$8-10$ & 4.51 \\
$10-15$ & 3.11 \\
$15-20$ & 4.24 \\
\hline
\end{tabular}

Source: The author's calculations

Hence, a non-linear relationship between inflation and GDP growth is indicated according to Figure 2. As highlighted by Burdekin et al. 2000, the statistical significance of this non-linear relationship and the growth maximising inflation rate need to be examined to recognize a possible structural break in per capita GDP growth rate.

Figure 2: Non-linear relationship between Inflation and per capita GDP growth

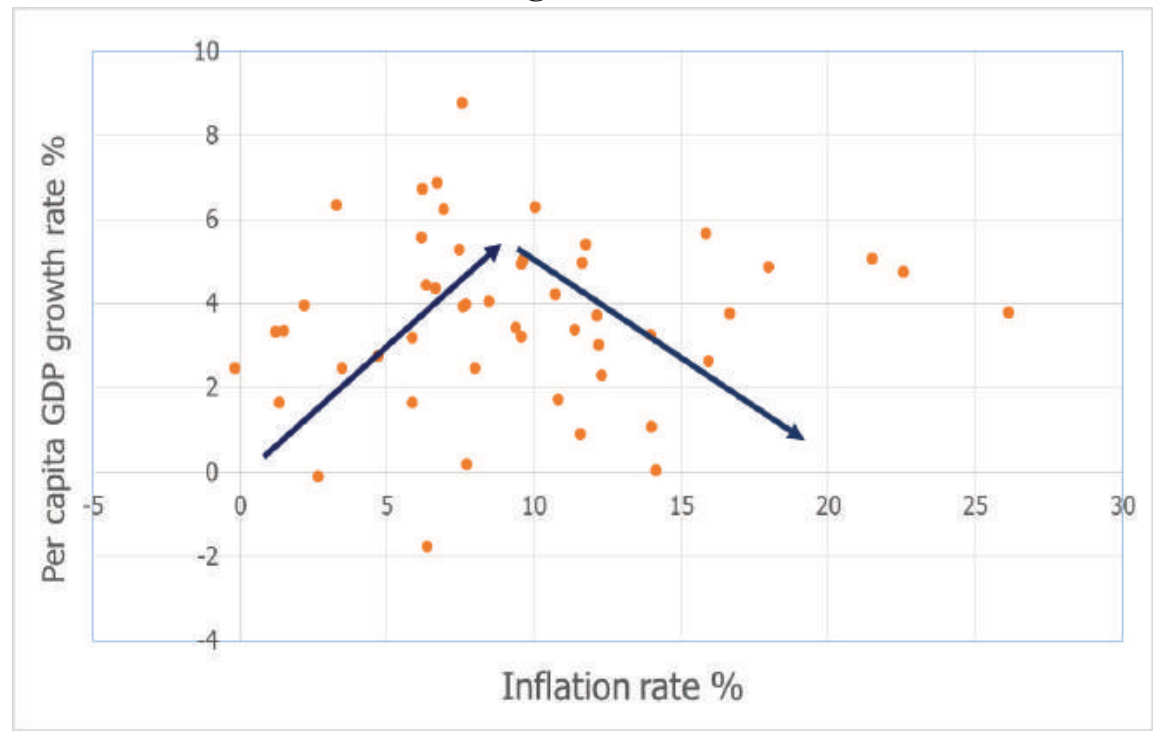

Source: The author's findings 
Accordingly, the null hypothesis to be tested in this study is that;

$\mathrm{H}_{0}$ : the inflation rate and per capita GDP growth rate has a non- linear relationship and a threshold level of inflation exists for Sri Lanka.

A similar approach to Sarel (207), Singh (377), and Hayat and Kalirajan (18) is used in this study to examine the threshold level of inflation in Sri Lanka and to assess whether that threshold level is statistically significant. The data obtained from the World Bank website and the Central Bank of Sri Lanka (CBSL) for the period 1965-2014 are used in this study. The period of this study is reasonable, given that it covers a variety of inflation episodes in Sri Lanka (as in Figure 1), while at the same time data on most other variables are reliably available beyond 1965.

\subsection{Estimating the growth equation}

To examine the inflation- growth nexus in Sri Lanka, this study uses the model based on the studies of Barro (423), De Gregorio (59), Levine and Renelt (942), Sala-i-Martin (178), Bruno and Easterly (3), Singh and Kalirajan (377), and Hayat and Kalirajan (8). These empirical studies have emphasized inflation, education and life expectancy variables, capital formation, agriculture value addition, export growth, and money supply (M2) and population growth as the main determinants of growth, among others. Literacy rate is also included in the model since it can affect growth through human capital development. Human capital, education and health are more likely to contribute to GDP by improving productivity. This principle can also be adopted in a single country time series data, ensuring that the variables entering the regression are stationary (Singh \& Kalirajan 377).

The present model utilises those potential growth variables suggested in the literature together with a new variable - Foreign Direct Investment (FDI) and Balance of Payments (BOP). The objective is to identify a model with higher explanatory power for analysing the relationship between growth and inflation. Following Hayat and Kalirajan, the estimation begins with two lagged variables for inflation and per capita GDP growth separately (9). Subsequently, other important control variables are included in to the model to test the strength of the inflation coefficient. Accordingly, the following model has been applied to the Sri Lankan context.

$$
\begin{aligned}
& \mathrm{dl}(\text { ypc })_{t}=\beta_{o}+\beta_{1 \mathrm{i}} \mathrm{dl}(\text { ypc })_{\mathrm{t}-\mathrm{i}}+\beta_{2 \mathrm{i}}(\mathrm{INF})_{\mathrm{t}-\mathrm{i}}+\beta_{3 \mathrm{i}} \mathrm{dl}(\mathrm{Cf})_{\mathrm{t}}+\beta_{4 \mathrm{i}} \mathrm{dl}(\mathrm{M} 2)_{t}+ \\
& \beta_{5 i} \mathrm{dl}(\mathrm{FDI})_{t}+\beta_{6 \mathrm{i}} \mathrm{dl}(\mathrm{lit})_{t}+\beta_{7 i} \mathrm{dl}(\mathrm{X})_{\mathrm{t}}+\epsilon_{1 \mathrm{t}}
\end{aligned}
$$

$\mathrm{dl}(\mathrm{ypc})_{\mathrm{t}} \quad-$ Growth in GDP per capita in period ' $\mathrm{t}$ ';

$\mathrm{INF}_{\mathrm{t}} \quad$-Rate of inflation in period ' $\mathrm{t}$ ';

$\mathrm{dl}(\mathrm{Cf})_{\mathrm{t}} \quad$-Growth in gross capital formation (\% of GDP) in period ' $\mathrm{t}$ '; 
dl(M2) $\quad$-Growth in broad money supply in period ' $t$ ';

$\mathrm{dl}(\mathrm{FDI})_{\mathrm{t}}-$ Growth in foreign direct investments (\% of GDP) in period ' $\mathrm{t}$ ';

dllit $_{\mathrm{t}} \quad-$ Growth in literacy rate $(\%)$ in period ' $\mathrm{t}$ ';

$\mathrm{dl}(\mathrm{X})_{\mathrm{t}} \quad-$ Growth in exports as percentage of GDP in period ' $\mathrm{t}$ ';

BOP -Balance of payments as a percentage of GDP in period ' $t$ ';

$\epsilon_{1 \mathrm{t}} \quad$-the stochastic term.

To start with a reduced form, VAR is used to test whether there is any bi-directional causality between GDP per capita growth (dlypc) and inflation (INF). Due to the relatively small size of the time series data, the order of the VAR is decided on by using the Schwarz Bayesian Criterion (SBC) of model selection. A lag length of two is selected accordingly. This study involves lagged terms of inflation and per capita growth (YPC growth) to find any bidirectional causality. Next, using equation (1), the potential effect of lagged inflation is tested using the Ordinary Least squares (OLS) regression, having taken into consideration all the relevant significant explanatory variables.

\subsection{The threshold level of inflation}

The threshold level of inflation has been examined by Sarel (203), Singh and Kalirajan (377) for India, Mubarik (35) for Pakistan, and later Hayat and Kalirajan (8) for Bangladesh, by utilizing a well specified functional form. In this study, by following Sarel (1996), and Hayat and Kalirajan (2009) in particular to examine the threshold level of inflation for Sri Lanka, the dummy variables are introduced to the basic model to incorporate the concept of extra inflation that is the effect caused by higher actual inflation above the threshold level. Accordingly equation 2 will be estimated using the Ordinary Least Squares (OLS) regression and is iterated with different PIDE i variables.

First, let $\mathrm{INF}^{*}$ be the rate of inflation at the structural break.

Next, a dummy variable is defined as,

D $2=1$ if actual INF in period $\mathrm{t}>\mathrm{INF} *$, and D $2=0$ otherwise,

(i $=4,5,6$

Thirdly, a new variable for the excess inflation over INF* is termed as,

PIDE $\mathrm{i}=\mathrm{D} 2 *(\mathrm{INF}-\mathrm{INF} *) \quad$ where $\mathrm{i}$ is the value of INF*.

Thus, for example, the coefficient of PIDE 7 represent the effect of excessive inflation beyond the inflation threshold INF* of 7 percent. 
$\mathrm{dl}(\mathrm{ypc})_{t}=\beta_{1}+\beta_{2} \mathrm{dl}(\mathrm{ypc})_{\mathrm{t}-1}+\beta_{3}(\mathrm{dlypc})_{\mathrm{t}-2}+\beta_{4}(\mathrm{INF})_{\mathrm{t}}+\beta_{5}(\mathrm{INF})_{\mathrm{t}-2}+$

$\beta_{6} \mathrm{dl}(\mathrm{Cf})_{\mathrm{t}-1}+\beta_{7} \mathrm{dl}(\mathrm{M} 2)_{t}+\beta_{8} \mathrm{dl}(\mathrm{lit})_{t-1}+\beta_{9} \mathrm{dl}(\mathrm{FDI})_{t}+\beta_{10} \mathrm{dl}(\mathrm{X})_{\mathrm{t}}+$

$\beta_{11} \mathrm{BOP}_{\mathrm{t}-1}+\beta_{12} \mathrm{PIDE}_{\mathrm{i}}+\epsilon_{1 \mathrm{t}}$

The iteration of the regression with PIDE $\mathrm{i}$ and INF as the regressors produce a series of regression statistics corresponding to different chosen values of INF*. As suggested by Singh and Kalirajan (377), the applicable estimators for contemporaneous inflation are: When inflation is low (INF $<$ INF*), the PIDE $i=0$, and the related estimator for inflation is INF. However when inflation is high (INF $>\mathrm{INF}^{*}$ ), then the relevant estimator is the sum of the two coefficients: the coefficient of INF and PIDE i.

According to Hayat and Kalirajan, running iterative regressions at different chosen threshold values will result in finding the value at which a significant structural break occurs with the largest R2 and F-value (8). It is also required that the sum of the coefficients of both the INF and PIDEi variables be positive and statistically significant to be considered as the threshold level of inflation. The coefficient of PIDEi will explain the variance in the inflation effect on growth before and after the structural break and the significance of the threshold is determined by its t-statistic value (Sarel 208).

\section{Estimation results and analysis}

According to Table 2, during the last 50 years, the mean figure of the annual average per capita GDP (YPC) of Sri Lanka is USD 859 and average annual inflation rate is 9.26 percent. The average of the year on year growth in GDP per capita income (DLYPC) is 3.8 percent. The average literacy rate during the last 50 years is approx. 88 percent. Further, an average of approx. 1 per cent growth in population is evidenced. 
Table 2: Descriptive Statistics

\begin{tabular}{|c|c|c|c|c|c|c|c|c|c|}
\hline & YPC & INF & CF & AGRI & BOP & FDI & POP & LIT & M2 \\
\hline Mean & 859 & 9.26 & 23.28 & 22.839 & -4.394 & 0.819 & 16582900 & 87.921 & 32.124 \\
\hline Median & 693 & 8.21 & 24.262 & 26.328 & -3.8 & 0.925 & 16920000 & 86.778 & 31.714 \\
\hline Maximum & 2136 & 26.15 & 33.768 & 33.165 & 3.5 & 2.850 & 20869000 & 91.181 & 41.716 \\
\hline & & - & & & & & & & \\
\hline Minimum & 353 & 0.156 & 12.531 & 9.860 & -16.4 & 0.030 & 11164000 & 86.778 & 17.946 \\
\hline Std. Dev. & 464 & 5.693 & 5.237 & 7.009 & 3.443 & 0.673 & 2968150 & 1.857 & 6.311 \\
\hline Skewness & 1.082 & 0.740 & -0.387 & -0.660 & -0.836 & 0.454 & -0.23116 & 0.997 & -0.316 \\
\hline Kurtosis & 3.350 & 3.643 & 2.24 & 1.939 & 4.846 & 2.919 & 1.753917 & 2.020 & 2.137 \\
\hline Jarque-Bera & 10.020 & 5.429 & 2.453 & 5.980 & 12.928 & 1.730 & 3.680 & 10.286 & 2.384 \\
\hline Probability & 0.007 & 0.066 & 0.293 & 0.050 & 0.002 & 0.421 & 0.159 & 0.006 & 0.304 \\
\hline Observations & 50 & 50 & 50 & 50 & 50 & 50 & 50 & 50 & 50 \\
\hline
\end{tabular}

\begin{tabular}{lcccccc}
\hline \hline & DLYPC & DLCF & DLAGRI & DLFDI & DLOPOP & DLM2 \\
\hline Mean & 0.038 & 0.007 & -0.026 & -0.075 & 0.011 & 0.005 \\
Median & 0.039 & 0.014 & -0.028 & -0.009 & 0.013 & 0.014 \\
Maximum & 0.088 & 0.268 & 0.195 & 3.252 & 0.023 & 0.164 \\
Minimum & -0.017 & -0.242 & -0.340 & -4.907 & -0.026 & -0.160 \\
Std. Dev. & 0.021 & 0.104 & 0.076 & 1.106 & 0.008 & 0.071 \\
Skewness & -0.293 & -0.057 & -0.930 & -1.589 & -2.910 & -0.060 \\
Kurtosis & 3.367 & 4.123 & 9.936 & 12.001 & 12.884 & 3.427 \\
Sum & 1.565 & 0.302 & -1.060 & -3.069 & 0.452 & 0.214 \\
Sum Sq. Dev. & 0.017 & 0.430 & 0.232 & 48.959 & 0.003 & 0.201 \\
\hline
\end{tabular}

According to Table 3, the Augmented Dicky-Fuller (ADF) test for the stationarity of the variables shows that all variables used in the regression model are stationary at their levels. The trend graphs for all time-series variables and the appropriate lag difference have been taken into consideration. 
Table 3: Unit root test results

\begin{tabular}{lccc}
\hline \hline Variables & $\begin{array}{l}\text { ADF Test } \\
\text { Statistic }\end{array}$ & $\begin{array}{l}\text { Critical } \\
\text { Value }\end{array}$ & Stationary \\
\hline GDP per capita growth (dlypc) & $-4.478^{* * *}$ & -3.574 & $\mathrm{I}(0)$ \\
Inflation (inf) & $-4.631^{* * *}$ & -3.571 & $\mathrm{I}(0)$ \\
Gross capital growth (dlcf) & $-6.606^{* * *}$ & -3.574 & $\mathrm{I}(0)$ \\
M2 growth (dlm2) & $-5.575^{* * *}$ & -3.574 & $\mathrm{I}(0)$ \\
Exports growth (dlx) & $-6.647^{* * *}$ & -3.574 & $\mathrm{I}(0)$ \\
Agriculture V.A. growth (dlagri) & $-6.415^{* * *}$ & -3.574 & $\mathrm{I}(0)$ \\
Literacy rate growth (dllit) & $-6.963^{* * *}$ & -3.574 & $\mathrm{I}(0)$ \\
BOP & $-4.387^{* * *}$ & -3.571 & $\mathrm{I}(0)$ \\
FDI growth (dlfdi) & $-3.456^{* *}$ & -2.939 & $\mathrm{I}(0)$ \\
& & & \\
\hline
\end{tabular}

Notes: ${ }^{* * *}$ significant at the $1 \%$ level, ${ }^{* *}$ significant at the $5 \%$ level

\subsection{Estimating the growth equation}

This paper attempts to estimate a well specified model to explain the growth inflation relationship. Thus, at the outset, the estimation started with two lags of inflation and per capita growth. Subsequently, other important controlling variables such as Gross Capital formation, Money supply growth, Export growth, FDI growth, literacy rate growth and BOP have been included to test the robustness of the inflation coefficient (Hayat \& Kalirajan 8). Since we can suspect a bi-directional causality between inflation and growth, a bi-variate reduced form VAR can be used or pair-wise Granger causality test can be performed to test such a causality. However, Temple argues that if the inflation variable is $\mathrm{I}(0)$, as in this study, a bi-variate reduced form VAR or the Granger causality test between inflation and GDP per capita growth rate is uninformative, hence, the inflation effects on GDP per capita growth should be estimated within a full structural model (410).

According to Model 1, only per capita GDP growth of lag 1 shows a positive significant effect on per capita GDP growth, while inflation lags of one and two show no significant effect on per capita GDP growth. However, the inflation lag of one period shows a significant positive effect on the Inflation variable. According to the SBC lag length criteria, two lags of inflation and per capita GDP growth are chosen and other important variables which may have an effect on per capita GDP growth and inflation are included. Any variable that is economically and statistically insignificant at a 10 percent level of significance has been taken out from the regression model and accordingly, the growth equation has been estimated with important controlled variables only. 
Finally, as shown in Table 4 (Appendix A), Model 2 is selected as the best specified model due to the inclusiveness of important determinants of per capita GDP growth and due to the statistical significance of most variables. Further, this model gives the highest adjusted $\mathrm{R}^{2}$ value of 0.65 for GDP per capita growth. Therefore, this can be the representative model to analyse the inflation- growth nexus in Sri Lanka. It is worth mentioning that in Model 1, an inflation lag of two periods, which showed no significance in explaining the GDP per capita growth, becomes significant when other important control variables are added to the model. This implies its increasing robustness on growth after controlling other explanatory variables.

The important features of the well specified model (Model 2) are summarized as follows. DLYPC(-1) and DLYPC(-2), which represent one period lag and two period lags of GDP per capita growth rates, respectively, show significant positive effects on the GDP per capita growth rate of Sri Lanka. Further, the inflation lag of one period and inflation lag of two periods show a positive effect on GDP per capita growth rate, yet only the inflation lag of two periods is statistically significant at a 5 percent level of significance. The positive relationship of lagged inflation and the GDP per capita growth of Sri Lanka has previously been highlighted by Cooray (2013). Furthermore, Malik and Chowdhary have also emphasised the long run positive relationship between inflation and growth in Sri Lanka, India, Bangladesh and Pakistan (123). One period lag of the growth in gross capital formation has a highly significant positive effect on DLYPC.

It is noteworthy that growth in the current period gross capital formation (DLCF) has no significant impact on GDP per capita growth rate, but the growth in the capital formation lag of one period (DLYPC(-1)) shows a positive relationship with GDP per capita growth rate at the one per cent significant level. It is an indication that the capital formation takes some time to have an effect on growth in Sri Lanka. In favor of this result, Mundel and Tobin (671) ${ }^{5}$ cited in Dutta and Mukhopadhyay predict a positive relationship between the rate of inflation and the rate of capital formation (416). They argue that inflation reduces people's wealth due to the decline in the rate of return on individual's real money balances. Thus, households save more by switching to assets, in order to accumulate desired wealth and subsequently, greater savings lead to greater capital accumulation which expedites the output growth. Model 2 also discovers a significant positive contribution of export growth to GDP per capita growth rate, as expected. An unexpected feature in this model is that the growth in money supply (DLM2) has a highly significant negative effect on GDP per capita growth rate.

Next, the potential effect of current inflation has been tested using the OLS regression in the most well specified model, having taken into consideration all the relevant significant

\footnotetext{
${ }^{5}$ The Tobin and Mundel effect (1965) explains that an increase in inflation increases capital formation in the long run.
} 
explanatory variables. The impact of contemporaneous inflation along with two lags of inflation has been examined in Model 3 (Table 5 Appendix B). Accordingly, it can be seen that the inclusion of contemporaneous inflation along with other significant controlled variables has improved the goodness-of-fit from 64 per cent to 66 per cent without any change in significance or signs of the variables. Furthermore, the unbiasedness of the estimated OLS coefficients has been tested using diagnostic tests such as the Durbin Watson test for Serial Autocorrelation, ARCH (2) test for Heteroscedasticity and residual normality tests (Appendix $\mathrm{E}, \mathrm{F})$ for which the results have been reported in the respective tables.

It is noteworthy that the negative effect of contemporaneous inflation on the GDP per capita growth is not statistically significant. The sum of the inflation coefficients is almost zero. According to the Wald test of coefficient restriction, the null hypothesis that the sum of the two coefficients being zero, is not rejected. This means that the significant positive effects of inflation that is realized after a gap of two years is neutralized by the negative effects of the contemporaneous change in inflation.

The statistically significant positive relationship between per capita GDP growth and the inflation lag of two periods suggest that the per cent 1 increase in prices (ie. inflation) has led to an increase in 0.1 per cent GDP per capita growth after a period of two years. It is important to analyze how lagged inflation must have affected the per capita GDP growth positively in Sri Lanka.

Inflation in Sri Lanka is measured by the Colombo Consumer Price Index (CCPI) and more than 53 percent of the CCPI is contributed by food items (CBSL 85). Therefore, price rises in agricultural food such as rice and other cereals should have greatly contributed to the rise in CPI. Ceriani et al. reveal that there has been a greater poverty reduction in Sri Lanka, when compared with other countries in South Asia. According to their findings, the contributory factors for the sharp reduction in monetary poverty which occurred in Sri Lanka over the last decade was mainly due to the growth in labour income (12). Such labour income growth accounted for about 60 per cent of the reduction in poverty in the South Asian countries: Bangladesh, Nepal and Sri Lanka (which is measured by the US\$1.25 a-day poverty line).

The salient result from Ceriani et al. is that most of the growth in labour incomes of the poor in Sri Lanka is due to the higher income to self-employed farm workers and salaried nonfarm workers, which is a result of the increase in commodity food prices (12). Therefore, it can be argued that although inflation in Sri Lanka has contemporaneous negative effects on per capita GDP growth, the inflation lag of two years bring positive effects on per capita GDP growth for the self-employed agriculture workers.

It is noteworthy that the robustness of the estimated regression results is tested by analysing to what extent the assumptions of the ordinary least squares regression are valid in this study. The estimation of the growth equation has been carried out using the OLS regression and 
these estimates have been used to identify the inflation threshold for Sri Lanka. Hence, the study tests whether the OLS assumptions are valid in this context and confirms that the residuals of regressions are normally distributed with mean zero and constant variance (Appendix D, E). The residuals are confirmed to be homogenous and no serial correlation exists (Appendix F) and thus, the regression estimates in this study are considered as unbiased and efficient estimates.

\subsection{Estimation of threshold level of inflation for Sri Lanka}

In order to examine whether there is any structural break for GDP per capita growth in Sri Lanka, Model 3 has been chosen as the basic model due to its highest explanatory power and also due to the statistical and economical significance of the variables (Hayat \& Kalirajan 8). In this model, current inflation, inflation which lagged two years, growth in gross capital formation, growth in broad money supply, export growth, growth in literacy levels, FDI growth, BOP have been included for the analysis of the threshold level of inflation. In fact, 17 values of INF* or threshold inflation from the range between 4 and 20 have been chosen for the iteration as PIDE 4, PIDE 5,..,PIDE 20. The following model is regressed with different PIDE values.

$$
\begin{aligned}
& \operatorname{dl}(\text { ypc })_{t}=\beta_{1}+\beta_{2} d_{l}(y p c)_{t-1}+\beta_{3}(\text { dlypc })_{t-2}+\beta_{4}(\text { INF })_{t}+\beta_{5}(\text { INF })_{t-2}+ \\
& \beta_{6} \mathrm{dl}(\mathrm{Cf})_{\mathrm{t}-1}+\beta_{7} \mathrm{dl}(\mathrm{M} 2)_{t}+\beta_{8} \mathrm{dl}(\text { lit })_{t-1}+\beta_{9} \mathrm{dl}(\mathrm{FDI})_{t}+\beta_{10} \mathrm{dl}(\mathrm{X})_{\mathrm{t}}+ \\
& \beta_{11} \mathrm{BOP}_{\mathrm{t}-1}+\beta_{12} \text { PIDE }_{\mathrm{i}}+\epsilon_{1 \mathrm{t}}
\end{aligned}
$$

The iteration generating a series of regression statistics corresponding to different chosen values of INF* (threshold inflation) shows that the 9 per cent (corresponds to PIDE 9) threshold inflation level, both $\mathrm{R}^{2}$ and F-statistics is the maximum (Appendix G). Further, the coefficient of PIDE 9 is also statistically significant at the 5 per cent significance level (Refer Model 5, Table 6 in Appendix C). It should be noted that the coefficients of PIDE 4 to PIDE 20 are all positive but statistically insignificant at any level of significance in the respective regressions, yet, the coefficients of lagged inflation are positive and significant at a 5 per cent level of significance (Appendix D). The contemporaneous inflation has a negative relationship with GDP per capita growth, but it is not statistically significant.

Figure 3 and Figure 4 present the series of R square values and log likelihood values plotted against the different values of chosen inflation threshold. From Figure 3 and Figure 4 it can be said that the structural break occurs at the 9 per cent level of inflation in Sri Lanka (Sarel 203). However, in order to interpret 9 per cent inflation level as the threshold inflation for Sri Lanka, this structural break should be statistically significant. The significance of the threshold level at 9 per cent can be examined by using the Wald test to test whether the sum of the inflation coefficients are significantly different from zero. 
Figure 3: $\mathbf{R}$ square values of the series of regressions

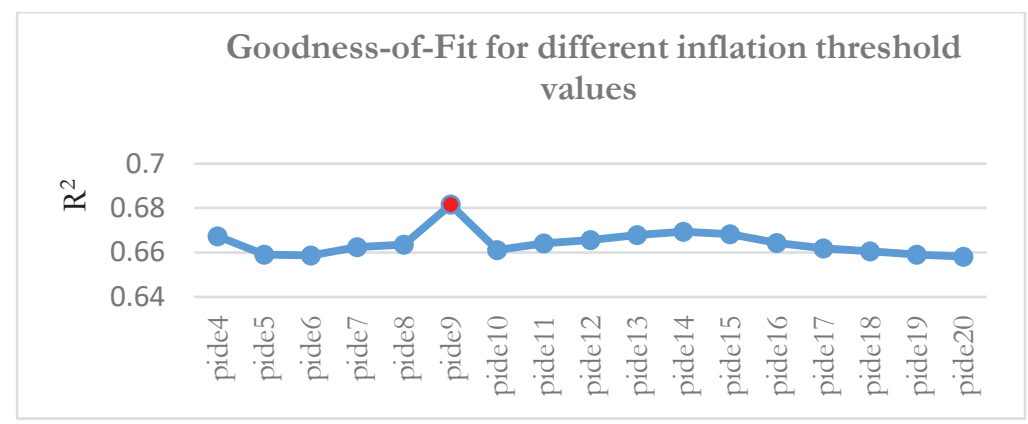

Figure 4: Log likelihood values of the series of regressions

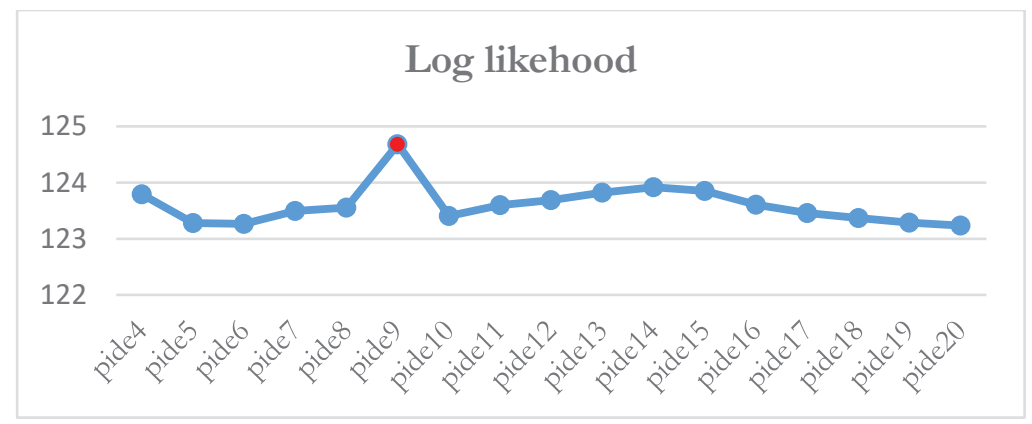

According to Singh and Kalirajan, at some value of INF*, the log likelihood of the regression is maximized (and the sum of the squared residuals is minimized) but the value of INF* at which the sum of the coefficients of INF and PIDE i significantly change signs (positive to negative) may be less than at INF* (385). Therefore, the analysis of the entire set of coefficients is equally important in deciding the target inflation level. To be precise, if the previously identified 9 percent inflation rate is to be a significant threshold, then at a 10 percent inflation rate, the sum of inflation coefficients has to be significantly negative, implying that beyond the single digit inflation, there should be adverse effects for the per capita income growth of Sri Lanka.

The Wald test results in Table 7 highlight that the sum of coefficients of contemporaneous inflation, lagged inflation and PIDE variable are all almost zero at all chosen values of the threshold inflation (Appendix D). Further, the P values of the Wald test indicate that the said positive effect of inflation variables towards the GDP per capita growth rate in Sri Lanka are not statistically significant. This clearly suggests that there is no significant structural break in the inflation-growth nexus in Sri Lanka. Further, as highlighted in Singh and Kalirajan, the 
non-existence of a structural break (390) can also be visualized from the observation of the plots of the R square and the plots of the log-likelihood for these models in Figures 3 and 4. These curves are flat and not much of a slope can be seen from either side of these curves. Similar results of the inflation threshold level have been identified by Singh for India (3209) and Hayat and Kalirajan for Bangladesh, and those studies concluded that such inflation thresholds found are not statistically significant (18).

Table 7: Wald Test Results for Inflation variables

\begin{tabular}{llll}
\hline \hline $\begin{array}{l}\text { Model with } \\
\text { Extra } \\
\text { Inflation } \\
\text { Variable }\end{array}$ & $\begin{array}{l}\text { Sum of the inflation } \\
\text { coefficients }\end{array}$ & $\begin{array}{l}\text { Wald Test for Sum } \\
\text { of Co-efficient (H0) }\end{array}$ & $\begin{array}{c}\text { F value } \\
\text { (P value) }\end{array}$ \\
\hline PIDE 8 & $\beta_{4}+\beta_{5}+\beta_{12}=0.000582$ & $H_{0}: \beta_{4}+\beta_{5}+\beta_{12}=0$ & $\begin{array}{l}0.599 \\
(0.445)\end{array}$ \\
PIDE 9 & $\beta_{4}+\beta_{5}+\beta_{12}=0.000795$ & $\mathrm{H}_{0}: \beta_{4}+\beta_{5}+\beta_{12}=0$ & 1.181 \\
& $\beta_{4}+\beta_{5}+\beta_{12}=0.000623$ & $\mathrm{H}_{0}: \beta_{4}+\beta_{5}+\beta_{12}=0$ & $0.550)$ \\
PIDE 10 & & & $(0.464)$ \\
\end{tabular}

Accordingly, it is evident that the inflation threshold at 9 per cent is not statistically significant and moreover, this study suggests that there is no negative effect of inflation towards the GDP per capita growth at any rate of inflation in Sri Lanka. This is an indication that any adverse effects of contemporaneous inflation are neutralized from the significant positive effects from the inflation lag of two periods. Further, it is also can be explained that beyond the 9 per cent inflation rate, there are neither significant positive nor negative cumulative effects from inflation variables towards the GDP per capita growth rate in Sri Lanka.

\section{Conclusion}

Policymakers throughout the world during the last decade have acted on the understanding that lowering inflation is conducive to higher growth performance. Taking into consideration one of the main objectives of the Central Bank of Sri Lanka, which is to maintain price stability, this study sheds light on important policy actions taken by the Central Bank. As Mohanty et al. emphasise, inflation targeting and the inflation threshold are two different concepts, where under the inflation targeting mechanism, a central bank announces a 'target' and then directs its policy tools towards achieving that target (14). Inflation threshold is a point of inflection for the growth-inflation relationship. Therefore, Mohanty et al. suggest that the inflation threshold need not necessarily be the 'target' of monetary policy in the Central Bank (14). The target level of inflation for monetary policy should be lower than the inflation threshold, considering the existence of significant lags in the transmission of monetary policy measures and the costs of inflation. 
In view of the above, this study mainly aimed at identifying a non-linear relationship between inflation and per capita GDP growth in Sri Lanka. The estimated results based on annual data from 1965 to 2014 reject the null hypothesis that the inflation rate and per capita GDP growth rate have a non-linear relationship, and that a threshold level of inflation exists for Sri Lanka. Therefore, there is no statistically significant evidence to suggest that there exists a non-linear relationship between per capita GDP growth and rate of inflation in Sri Lanka. The study reveals an inflation rate of 9 per cent, which maximises the per capita GDP growth rate. However, the results do not confirm any significant structural break in per capita GDP growth rate when the inflation rate exceeds 9 per cent. Interestingly, this level of inflation rate of 9 per cent is closer to the inflation threshold of 8 per cent suggested by Sarel in his study, where Sri Lanka was also included (199). Furthermore, a new series of GDP and CCPI have been released since conducting this research study, which may lead to a change in the results of this study if those new series are used.

Moreover, some conjectures can be made for the statistical insignificance of the inflation threshold such as errors in data, and not including the savings and investments variables. Due to the lack of data, this study could not incorporate the savings and investment variables to test how the inflation will effect growth, through changes in savings and investments in Sri Lanka. As explained by Tobin and Mundell, higher inflation leads to lower real interest rates and in turn lead to portfolio adjustment away from real money balance towards real capital (671). Hence, an increase in real investment will result in faster growth. Another limitation of this study is that the impact on growth from core and headline inflation cannot be distinguished due to the lack of data. Thus, this is an important area for further research. Since core inflation is less volatile and can be anticipated to a greater extent than the headline or the noncore component of inflation, core inflation is likely to have a lower impact on long-term growth.

One of the important findings of this study is the non-existence of an inflation threshold for Sri Lanka. The identified 9 per cent growth maximising inflation threshold is not statistically significant. It can be further highlighted that the total effect from contemporaneous inflation and lagged effect of inflation towards the GDP per capita growth in Sri Lanka is not negative, as expected. Further, testing for the cumulative effect of inflation variables indicate that there is neither a significant positive effect nor a significant negative effect of inflation that exists for the per capita GDP growth rate of Sri Lanka. The results however are not in favour of the view for maintaining inflation at very low levels, since the per capita GDP growth is maximised at the inflation rate of 9 per cent. Since, Sri Lanka is an emerging economy, it is important to maintain inflation at a moderate level and prevent adverse effects to the economy either through very low inflation rates or through very high inflation rates. Thus, it suggests that maintaining inflation at single digital levels is prudent and in line with the Central Bank's objective of maintaining economic and price stability. 


\section{References}

Barro, RJ., "Inflation and economic growth", Annals of Economic and Finance, vol. 1, no. 14, 2013, pp. 85-109.

Barro, R., Inflation and growth, Handbook of Monetary and Fiscal Policy, 2001, pp. 423-442.

Burdekin, RCK, Denzau, AT, Manfred WK, Sitthiyot, T, \& Willett, TD., Working Papers in Economics, Claremont Colleges, 2000

Bruno, M \& Easterly, W. "Inflation crises and long-run growth", Journal of Monetary Economics, vol. 1, no. 41, 1998, pp. 3-26.

Barro, RJ., "Inflation and economic growth", NBER Working Paper Series, no. 5326, National Bureau of Economic Research, USA, 1995

Barro, RJ., "Economic growth in a cross section of countries", The Quarterly Journal of Economics, vol. 2, no. 106, 1991, pp. 407-443.

Ceriani, L, Inchauste, G \& Olivieri, S., "Understanding poverty reduction in Sri Lanka, Evidence from 2002 to 2012/13", Policy Research Working paper, no. 7446, Poverty Global Practice Group, World Bank Group, USA, 2015

Cooray, NS., "An empirical analysis of inflation-growth nexus in developing countries: the case of Sri Lanka”, International University of Japan, Japan, 2013

Central Bank of Sri Lanka, Objectives, functions and organization, Central Bank of Sri Lanka, Colombo, 2005

Datta, K \& Mukhopadhyay, CK., "Relationship between inflation and economic growth in Malaysia - An econometric review", International Conference on Economics and Finance Research, Singapore, 2011

De Gregorio, J. "Economic growth in Latin America", Journal of Development Economics, vol. 39, 1992, pp. 59-84.

Espinoza, R, Leon, H \& Prasad, A., "When should we worry about inflation?”, The World Bank Economic Review, vol. 26, no. 1, 2012, pp. 100-127.

Feldstein, M. "The costs of going from low inflation to price stability", NBER Working Paper series, No. 5469, National Bureau of Economic Research, Cambridge, 1996

Fischer, S., "The role of macroeconomic factors in growth", Journal of Monetary Economics, vol. 32, no. 3, 1993, pp. 485-512

Ghosh, A \& Phillips, S., “Warning: Inflation may be harmful to your growth”, IMF Staff Papers, vol. 45, no. 4, 1998, pp. 672-710.

Hayat, CZ \& Kalirajan, K., "Is there a threshold level of inflation for Bangladesh?”, The Journal of Applied Economic Research, vol. 3, 2009, pp. 1-20.

Hodge, D., "Inflation and growth in South Africa", Cambridge Journal of Economics, vol. 30, 2005, pp. 163-180. 
Jha, R \& Dang, N., "Inflation variability and the relationship between inflation and growth", Macroeconomics and Finance in Emerging Market Economies, vol. Online 14 Dec 2011, pp. 1-15.

Judson, R \& Orphanides, A., "Inflation, volatility and growth", International Finance, vol. 2, no. 1,1999, pp. 117-138.

Khan, MS \& Senhadji, AS., 2001, "Threshold effects in the relationship between inflation and growth", Technical Report, IMF Staff paper, no. 48, 2001

Levine, R \& Renelt, D., "A sensitivity analysis of cross-country growth regressions", The American Economic Review, vol. 82, no. 4, 1992, pp. 942-963.

Mohanty, D, Chakraborty, AT, Das, A \& John, J., "Inflation threshold in India: an empirical investigation", Department of Economic and Policy Research, Reserve Bank of India, 2011

Mubarik, YA., "Inflation and growth: an estimate of the threshold level of inflation in Pakistan", State Bank of Pakistan Research Bulletin, vol. 1, 2005, pp. 35-44.

Mallik, G \& Chowdhury, A., "Inflation and economic growth: evidence from four south Asian countries", Asia-Pacific Development Journal, vol. 8, no. 1, 2001, pp. 123-135.

Pollin, R \& Zhu, A., "Inflation and economic growth: A cross-country nonlinear analysis", Journal of Post Keynesian Economics, vol. 28, no. 4, 2006, pp. 593-614.

Phillips, AW., "Employment, inflation and growth", Economica, New Series, vol. 29, no. 113, 1962, pp. 1-16.

Seleteng, M., Bittencourt, M. and van Eyden, R., "Non-linearities in Inflation-Growth Nexus in the SADC Region: Panel Smooth Transition Regression Approach", Economic Modelling, vol. 30, 2013, pp. 149-156.

Singh, P., "Searching threshold inflation for India", Economics Bulletin, vol. 30, no .4, 2010, pp. 3209-3220.

Sepehri, A \& Moshiri, S., "Inflation-growth profiles across countries: evidence from developing and developed countries", International Review of Applied Economics, vol. 18, no. 2, 2004, pp. 191-207.

Singh, K \& Kalirajan, K., "The inflation-growth nexus in India: an empirical analysis", Journal of Policy Modeling, vol. 25, 2003, pp. 377-396.

Sala-i-Martin, XX., "I just ran two million regressions", The American Economic Review, vol. 87, no. 2, 1997, pp. 178-183.

Sarel, M., "Nonlinear effects of inflation on economic growth", IMF Staff Papers, 43(1), 1996, 199-215.

Temple, J., "Inflation and growth: Stories short and tall", Journal of Economic Surveys, vol. 14, no. 4, 2000, pp. $395-432$.

Tobin, J., "Money and economic Growth", Econometrica, vol. 33, 1965, pp. 671-684. 


\section{Appendices}

A. Table 4: Growth Equation

\begin{tabular}{|c|c|c|}
\hline & Model 1 & Model 2 \\
\hline & DLYPC & DLYPC \\
\hline \multirow[t]{2}{*}{ DLYPC(-1) } & $0.300^{* *}$ & $0.385^{* * *}$ \\
\hline & $(0.152)$ & $(0.129)$ \\
\hline \multirow[t]{2}{*}{ DLYPC(-2) } & 0.243 & $0.435^{* * *}$ \\
\hline & $(0.155)$ & $(0.142)$ \\
\hline \multirow[t]{2}{*}{$\operatorname{INF}(-1)$} & 0.000 & 0.0005 \\
\hline & $(0.001)$ & $(0.001)$ \\
\hline \multirow[t]{2}{*}{ INF(-2) } & 0.000 & $0.002^{* *}$ \\
\hline & $(0.001)$ & $(0.001)$ \\
\hline \multirow[t]{2}{*}{ C } & 0.018 & 0.004 \\
\hline & $(0.009)$ & $(0.008)$ \\
\hline \multirow[t]{2}{*}{ DLCF(-1) } & & $0.082^{* * *}$ \\
\hline & & $(0.025)$ \\
\hline \multirow[t]{2}{*}{ DLM2 } & & $-0.110^{* * *}$ \\
\hline & & $(0.034)$ \\
\hline \multirow[t]{2}{*}{ DLLIT(-1) } & & 0.444 \\
\hline & & $(0.407)$ \\
\hline \multirow[t]{2}{*}{ DLFDI } & & 0.003 \\
\hline & & $(0.002)$ \\
\hline \multirow[t]{2}{*}{ DLX } & & $0.118^{* *}$ \\
\hline & & $(0.038)$ \\
\hline \multirow[t]{2}{*}{ BOP(-1) } & & $0.003^{*}$ \\
\hline & & $(0.001)$ \\
\hline R-squared & 0.189 & 0.641 \\
\hline Adj. R-squared & 0.111 & 0.521 \\
\hline Log likelihood & 121.32 & 122.22 \\
\hline Akaike AIC & -4.95 & -5.43 \\
\hline
\end{tabular}

Notes: Values in parenthesis are standard errors. ***ignificant at $1 \%$ level, ** significant at $5 \%$ level, * significant at $10 \%$ level. 
B. Table 5: Growth Equation with Current year Inflation

\begin{tabular}{|c|c|}
\hline & Model 3 \\
\hline Variable & DLYPC \\
\hline \multirow[t]{2}{*}{ C } & 0.015 \\
\hline & $(0.009)$ \\
\hline \multirow[t]{2}{*}{ DLYPC(-1) } & $0.405^{* * *}$ \\
\hline & $(0.125)$ \\
\hline \multirow[t]{2}{*}{ DLYPC(-2) } & $0.337 * *$ \\
\hline & $(0.139)$ \\
\hline \multirow[t]{2}{*}{ INF } & -0.001 \\
\hline & $(0.001)$ \\
\hline \multirow[t]{2}{*}{ INF(-2) } & $0.002 * *$ \\
\hline & $(0.001)$ \\
\hline \multirow[t]{2}{*}{ DLCF(-1) } & $0.099 * * *$ \\
\hline & $(0.026)$ \\
\hline \multirow[t]{2}{*}{ DLM2 } & $-0.142^{* * *}$ \\
\hline & $(0.039)$ \\
\hline \multirow[t]{2}{*}{ DLLIT(-1) } & 0.654 \\
\hline & $(0.392)$ \\
\hline \multirow[t]{2}{*}{ DLFDI } & $0.004 *$ \\
\hline & $(0.002)$ \\
\hline \multirow[t]{2}{*}{ DLX } & $0.102^{* * *}$ \\
\hline & $(0.035)$ \\
\hline \multirow[t]{2}{*}{ BOP(-1) } & $0.002 * *$ \\
\hline & $(0.001)$ \\
\hline R-squared & 0.66 \\
\hline Adjusted R-squared & 0.54 \\
\hline DW Stat & 2.177 \\
\hline $\mathrm{LM} \quad$ (2) & $0.174(0.841)$ \\
\hline \multicolumn{2}{|l|}{ Correlation } \\
\hline $\begin{array}{l}\text { Heteroscedasticity } \\
\text { Test: ARCH }\end{array}$ & $0.774(0.469)$ \\
\hline
\end{tabular}

Notes: Values in parenthesis are standard errors. ***significant at 1\% level, ** significant at $5 \%$ level, * significant at $10 \%$ level. 
C.

Table 6: Threshold Level of Inflation for Sri Lanka

\begin{tabular}{|c|c|c|c|}
\hline & Model 4 & Model 5 & Model 6 \\
\hline Variable & DLYPC & DLYPC & DLYPC \\
\hline \multirow[t]{2}{*}{$\mathrm{C}$} & 0.022 & 0.027 & 0.020 \\
\hline & $(0.014)$ & $(0.012)$ & (0.013) \\
\hline \multirow[t]{2}{*}{ DLYPC(-1) } & $0.410^{* * *}$ & $0.424 * * *$ & $0.407 * * *$ \\
\hline & $(0.127)$ & $(0.124)$ & $(0.127)$ \\
\hline \multirow[t]{2}{*}{ DLYPC(-2) } & $0.321 * *$ & $0.291 * *$ & $0.319 * *$ \\
\hline & $(0.142)$ & $(0.140)$ & $(0.145)$ \\
\hline \multirow[t]{2}{*}{ INF } & -0.002 & $-0.003 * *$ & -0.002 \\
\hline & $(0.002)$ & $(0.001)$ & $(0.002)$ \\
\hline \multirow[t]{2}{*}{$\operatorname{INF}(-2)$} & $0.002 * *$ & $0.002^{* *}$ & $0.002 * *$ \\
\hline & $(0.001)$ & $(0.001)$ & $(0.001)$ \\
\hline \multirow[t]{2}{*}{$\operatorname{DLCF}(-1)$} & $0.100^{* * *}$ & $0.098^{* * *}$ & $0.099 * * *$ \\
\hline & $(0.026)$ & $(0.025)$ & $(0.026)$ \\
\hline \multirow[t]{2}{*}{ DLM2 } & $-0.146^{* * *}$ & $-0.145^{* * *}$ & $-0.144 * * *$ \\
\hline & $(0.040)$ & $(0.039)$ & $(0.040)$ \\
\hline \multirow[t]{2}{*}{ DLLIT(-1) } & $0.761 *$ & $0.772^{*}$ & $0.708^{*}$ \\
\hline & $(0.426)$ & $(0.393)$ & $(0.412)$ \\
\hline \multirow[t]{2}{*}{ DLFDI } & $0.005^{* *}$ & $0.005^{* *}$ & $0.005^{*}$ \\
\hline & $(0.002)$ & $(0.002)$ & (0.003) \\
\hline \multirow[t]{2}{*}{ DLX } & $0.107^{* * *}$ & $0.108^{* * *}$ & $0.105^{* * *}$ \\
\hline & $(0.037)$ & $(0.035)$ & $(0.036)$ \\
\hline \multirow[t]{2}{*}{$\mathrm{BOP}(-1)$} & $0.002 *$ & $0.001 *$ & $0.002^{*}$ \\
\hline & (0.001) & $(0.001)$ & $(0.001)$ \\
\hline \multirow[t]{2}{*}{ PIDE 8} & 0.001 & - & - \\
\hline & $(0.002)$ & & \\
\hline \multirow[t]{2}{*}{ PIDE 9} & - & 0.002 & - \\
\hline & & $(0.002)$ & \\
\hline \multirow[t]{2}{*}{ PIDE 10} & - & - & 0.001 \\
\hline & & & $(0.002)$ \\
\hline R-squared & 0.663 & 0.682 & 0.661 \\
\hline Adjusted R-squared & 0.536 & 0.561 & 0.532 \\
\hline DW Stat & 2.155 & 2.178 & 2.163 \\
\hline LM (2) Serial Correlation & $0.153(0.859)$ & $0.230(0.796)$ & $0.163(0.851)$ \\
\hline $\begin{array}{l}\text { Heteroscedasticity Test: } \\
\text { ARCH }\end{array}$ & $0.719(0.494)$ & $0.486(0.619)$ & $0.671(0.518)$ \\
\hline
\end{tabular}

Notes: Values in parenthesis are standard errors. *** significant at 1\% level, ** significant at $5 \%$ level, *significant at $10 \%$ level. 


\section{Residual Test - Histogram Normality Test of Model 3 (Table 5)}

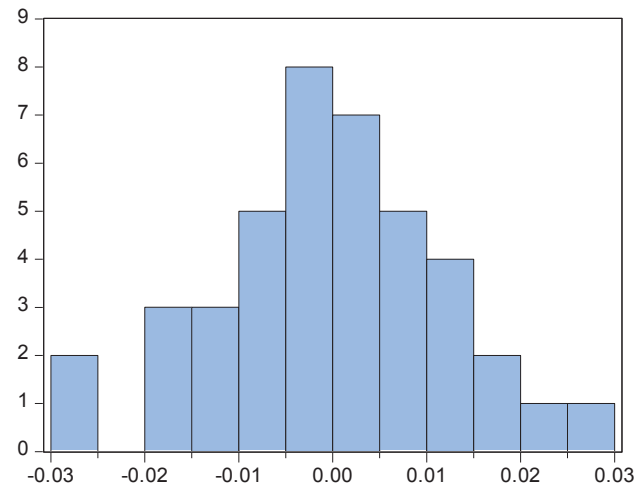

\begin{tabular}{|lc|}
\hline \multicolumn{2}{|l|}{ Series: Residuals } \\
Sample 1972 2014 \\
Observations & 41 \\
Mean & $3.31 \mathrm{e}-18$ \\
Median & -0.000524 \\
Maximum & 0.029201 \\
Minimum & -0.029625 \\
Std. Dev. & 0.012128 \\
Skewness & -0.205393 \\
Kurtosis & 3.174521 \\
& \\
Jarque-Bera & 0.340305 \\
Probability & 0.843536 \\
\hline
\end{tabular}

\section{E. Residual Test - Hetroskedasticity ARCH Test of Model 3 (Table 5)}

Heteroskedasticity Test: ARCH

\begin{tabular}{llll}
\hline \hline F-statistic & 0.773733 & Prob. F(2,34) & 0.4692 \\
Obs*R-squared & 1.610698 & Prob. Chi-Square(2) & 0.4469 \\
\hline \hline
\end{tabular}

Test Equation:

Dependent Variable: RESID^2

Method: Least Squares

Date: 11/13/15 Time: 09:25

Sample (adjusted): 19742014

Included observations: 37 after adjustments

\begin{tabular}{lrrrr}
\hline \multicolumn{1}{c}{ Variable } & Coefficient & Std. Error & t-Statistic & Prob. \\
\hline \multicolumn{1}{c}{ C } & 0.000171 & $5.53 \mathrm{E}-05$ & 3.098538 & 0.0039 \\
RESID $^{\wedge} 2(-1)$ & -0.192785 & 0.172165 & -1.119769 & 0.2707 \\
\multicolumn{1}{c}{ RESID^2(-2) } & 0.051750 & 0.172783 & 0.299509 & 0.7664 \\
\hline \hline & & & \\
R-squared & 0.043532 & Mean dependent var & 0.000149 \\
Adjusted R-squared & -0.012730 & S.D. dependent var & 0.000223 \\
S.E. of regression & 0.000224 & Akaike info criterion & -13.88826 \\
Sum squared resid & $1.71 \mathrm{E}-06$ & Schwarz criterion & -13.75765 \\
Log likelihood & 259.9329 & Hannan-Quinn criter. & -13.84221 \\
F-statistic & 0.773733 & Durbin-Watson stat & 2.033046 \\
Prob(F-statistic) & 0.469240 & & \\
\hline \hline
\end{tabular}




\section{F. Residual Test - Serial Correlation Test of Model 3 (Table 5)}

Breusch-Godfrey Serial Correlation LM Test:

\begin{tabular}{llll}
\hline \hline F-statistic & 0.174073 & Prob. F(2,28) & 0.8411 \\
Obs*R-squared & 0.503526 & Prob. Chi-Square(2) & 0.7774 \\
\hline \hline
\end{tabular}

Test Equation:

Dependent Variable: RESID

Method: Least Squares

Date: 11/13/15 Time: 09:32

Sample: 19722014

Included observations: 41

Presample and interior missing value lagged residuals set to zero.

\begin{tabular}{lrcrr}
\hline \hline \multicolumn{1}{c}{ Variable } & Coefficient & Std. Error & t-Statistic & Prob. \\
\hline \hline C & -0.001334 & 0.009736 & -0.137038 & 0.8920 \\
DLYPC(-1) & 0.066565 & 0.173372 & 0.383944 & 0.7039 \\
DLYPC(-2) & -0.026705 & 0.208206 & -0.128261 & 0.8989 \\
INF & $-6.53 \mathrm{E}-05$ & 0.000610 & -0.107064 & 0.9155 \\
INF(-2) & $5.95 \mathrm{E}-05$ & 0.000527 & 0.113003 & 0.9108 \\
DLCF(-1) & -0.001596 & 0.026943 & -0.059244 & 0.9532 \\
DLM2 & -0.007485 & 0.042696 & -0.175308 & 0.8621 \\
DLLIT(-1) & -0.047782 & 0.428782 & -0.111436 & 0.9121 \\
DLFDI & 0.000467 & 0.002394 & 0.195189 & 0.8467 \\
DLX & -0.005284 & 0.038518 & -0.137193 & 0.8919 \\
BOP(-1) & $4.37 \mathrm{E}-06$ & 0.000872 & 0.005010 & 0.9960 \\
RESID(-1) & -0.171813 & 0.291260 & -0.589894 & 0.5600 \\
RESID(-2) & -0.000935 & 0.283093 & -0.003301 & 0.9974 \\
\hline \hline R-squared & 0.012281 & Mean dependent var & $3.31 \mathrm{E}-18$ \\
Adjusted R-squared & -0.411027 & S.D. dependent var & & 0.012128 \\
S.E. of regression & 0.014406 & Akaike info criterion & -5.389508 \\
Sum squared resid & 0.005811 & Schwarz criterion & & -4.846180 \\
Log likelihood & 123.4849 & Hannan-Quinn criter. & -5.191658 \\
F-statistic & 0.029012 & Durbin-Watson stat & 1.992748 \\
Prob(F-statistic) & 1.000000 & & & \\
\hline \hline
\end{tabular}




\section{G. Table 7: Regression results and sum of inflation coefficients of the iterations done using PIDE 4 to PIDE 9}

\begin{tabular}{|c|c|c|c|c|c|c|}
\hline $\begin{array}{l}\text { Model } \\
\text { with }\end{array}$ & $\mathrm{R}$ square & log like & $\beta_{4}$ & $\beta_{5}$ & $\beta_{12}$ & $\beta_{4}+\beta_{5}+\beta_{12}$ \\
\hline pide4 & 0.667 & 123.790 & -0.00548 & $0.00130^{* *}$ & 0.00467 & 0.00048 \\
\hline pide 5 & 0.659 & 123.283 & -0.00015 & $0.00130^{* *}$ & -0.00074 & 0.00041 \\
\hline pide6 & 0.659 & 123.262 & -0.00011 & $0.00126^{* *}$ & -0.00078 & 0.00037 \\
\hline pide7 & 0.662 & 123.494 & -0.00226 & $0.00129 * *$ & 0.00144 & 0.00046 \\
\hline pide8 & 0.664 & 123.556 & -0.00202 & $0.00130 * *$ & 0.00130 & 0.00058 \\
\hline pide9 & 0.681 & 124.682 & $-0.00259 * *$ & $0.00120^{* *}$ & 0.00219 & 0.00080 \\
\hline pide10 & 0.661 & 123.406 & -0.00154 & $0.00129 * *$ & 0.00088 & 0.00062 \\
\hline pide11 & 0.664 & 123.597 & -0.00170 & $0.00129 * *$ & 0.00120 & 0.00080 \\
\hline pide12 & 0.666 & 123.688 & -0.00168 & $0.00128^{* *}$ & 0.00131 & 0.00091 \\
\hline pide13 & 0.668 & 123.821 & -0.00171 & $0.00127 * *$ & 0.00153 & 0.00108 \\
\hline pide14 & 0.669 & 123.918 & -0.00167 & $0.00125^{* *}$ & 0.00166 & 0.00124 \\
\hline pide15 & 0.668 & 123.852 & -0.00155 & $0.00123^{* *}$ & 0.00165 & 0.00132 \\
\hline pide16 & 0.664 & 123.606 & -0.00138 & $0.00124^{* *}$ & 0.00139 & 0.00125 \\
\hline pide17 & 0.662 & 123.457 & -0.00129 & $0.00125^{* *}$ & 0.00123 & 0.00120 \\
\hline pide18 & 0.660 & 123.372 & -0.00120 & $0.00126^{* *}$ & 0.00112 & 0.00118 \\
\hline pide19 & 0.659 & 123.288 & -0.00108 & $0.00127^{* *}$ & 0.00083 & 0.00102 \\
\hline pide20 & 0.658 & 123.234 & -0.00092 & $0.00128^{* *}$ & 0.00019 & 0.00054 \\
\hline
\end{tabular}

Notes: ** significant at $5 \%$ level, * significant at $10 \%$ level. 